\title{
SOCIAL PEDAGOGY AND SOCIOLOGY OF EDUCATION - IN A CIRCLE OF MUTUAL INSPIRATIONS
}

\begin{abstract}
Segiet Katarzyna, Social Pedagogy and Sociology of Education - in a Circle of Mutual Inspirations [Pedagogika społeczna i socjologia edukacji - wzajemne oddziaływania]. Studia Edukacyjne nr 55, 2019, Poznań 2019, pp. 79-91. Adam Mickiewicz University Press. ISSN 1233-6688. DOI: 10.14746/ se. 2019.55 .5
\end{abstract}

The state and future of scientific disciplines is largely determined by their background, numerous important events, discoveries, achievements, but above all, eminent experts, people of science. Thanks to these people, it was possible to conduct many analyses and research programs, which were reflected in multiple scientific studies. In the case of Polish social pedagogy, Helena Radlińska, Aleksander Kamiński and Ryszard Wroczyński have undoubtedly become such persons. On the other hand, Polish sociology of education should be strongly associated, among others, with Florian Znaniecki, Józef Chałasiński and Stanisław Kowalski.

In this article, I do not describe all the issues that are the focus of both subdisciplines. However, I would like to underline a few issues that I will present synthetically and which are personally important and interesting from the point of view of a social educator, namely: What are the sources of the emergence of social pedagogy as a scientific discipline and what associates it with the sociology of education; What priorities are imposed on social pedagogy and sociology of upbringing by the transformation of modern civilization and how are new social problems shaped in this context; finally how educational sociology has been an aid to social pedagogy and vice versa.

Key words: social pedagogy, sociology of upbringing, inspirations

\section{About social pedagogy and sociology of education}

To start pondering over social pedagogy and sociology of upbringing, it requires a return to what has already been said in numerous textbooks or scientific studies. There is no doubt that the rank of both subdisciplines is extremely important because both of them: social pedagogy and sociology of 
education deal with issues of environmental educational influences and problems related to the unsuccessful course of the upbringing process. A lot has been written about the origins and events of the past that have contributed to the emergence of social pedagogy, and it can even be said that we are currently experiencing a kind of renaissance of studies/textbooks for students showing the origin of this scientific subdiscipline. ${ }^{1}$

Wiesław Theiss in one of his studies on social pedagogy of the Second Polish Republic, characterizing Polish social pedagogy, stated that:

(...) it occurs in two main spins; "wide" (external) and "narrow" (internal). The first of these is combined with an attempt at a general typology of various currents and pedagogical trends of the 20th century. In this view, social pedagogy is part of the socalled pedagogical sociologism (sociological pedagogy), one of the great currents in contemporary pedagogy (alongside psychological pedagogy, cultural pedagogy and materialistic pedagogy). This movement rejects individualistic goals of education and assigns it the task of socializing the individual. The leading representatives of this pedagogical movement include such well-known authors as, John Dewey, Georg Kerschensteiner or Paul Natorp. In turn, the "narrow" (internal) perspective assumes that social pedagogy is a relatively separate sub-discipline within the sciences of education. It deals with the upbringing environment, builds theories of environmental conditions of education and development. It also has the appropriate procedures for organizing the educational environment. In Poland Helena Radlińska (1879 - 1954) is the creator of pedagogy understood in this way. It is a concept formed on the boundaries of the general theory of upbringing, sociology, adult education and social welfare, ${ }^{2}$

The ideological sources of social pedagogy certainly require meticulous research and careful analysis, nonetheless they should be sought at the turn of the XIX and XX century. W. Theiss, mentioned by me earlier, based on the views of researchers of currents and trends in Polish social pedagogy of that period, distinguished two ways of developing social pedagogy illustrating at the same time the background of situations in which social pedagogy was created, i.e.:

${ }^{1}$ The works of the following should be mentioned: S. Kawula, Social Pedagogy. Achievements - activity - perspectives, Torun 2001; the same author: Studies on social pedagogy, Olsztyn 1996; Social pedagogy, Eds. T. Pilch, I. Lepalczyk, Warsaw 1995; A. Radziewicz-Winnicki, Social pedagogy in the face of everyday reality, Warsaw 2008; Functioning and development directions of social pedagogy in Poland, Eds. E. Trempała, M. Cichosz, Olecko 2000; M. Cichosz, Polish social pedagogy in 1945-2003. Selection of source texts, vol. I, II, Torun 2004; the same author: Polish social pedagogy in 1945-2003. Development - areas of reflection and research - concepts. Presentation of academic centers, Eds. E. Trempała, M. Cichosz, Olecko 2000; E. Marynowicz-Hetka, Social pedagogy. Academic Handbook 1, Warsaw 2006.

${ }^{2}$ See W. Theiss, Social pedagogy of the Second Polish Republic (questions about scientific discourse), [in:] Social pedagogy. Tradition - The Present - New challenges, Eds. E. Trempała, M. Cichosz, Olecko 2001, p. 15. Referring to historical analysis according to W. Theissa it is mentioned by L. Chmaj, K. Sośnicki, B. Nawroczyński as well as R. Wroczyński and A. Kamiński. 
The first one - the path of struggle, committed action for independent Poland and the second one, based on the theory understood as a form of social practice ${ }^{3}$ associated with the need to build and reform education in reviving Poland. This is the path taken by Helena Radlińska, the creator of the compact concept of Polish social pedagogy, which is accompanied by reflection on "human development and educational reality: what it is (realities), what it should / could be (ideal, norm), what to do - if need be - to change this reality, pedagogically improve and develop (working method)? ${ }^{4}$

In turn, Helena Radlińska in 1913 in one of her published works, describing social pedagogy, presents her mission by writing:

(...) science, which could be described as the theory of national education - social pedagogy, shows in an increasingly emphatic way, how many relationships occur between the individual and society, as everyone - consciously or unconsciously - is a soul incarnated in their homeland (...). The task of national education is to bring out all the forces from the nation, direct them towards conscious work on building native culture $(\ldots) .^{5}$

H. Radlińska definitely presents a holistic view of social pedagogy and her peculiar point of view (theoretical and methodological foundations of social pedagogy) in her work The educator's attitude to the educational environment (1935). ${ }^{6}$ She completes the concept in the collective work Social causes of school success and failure (1937) and in the monograph on Adult Education (1947), bearing in mind the current socio-economic and political situation. Social policy and the sociology of education, that we find so interesting, played a role in the formation of theoretical (conceptual) assumptions.

Social pedagogy and sociology of upbringing were based on the intersecting influences of progressive ideas of enlightenment of the nineteenth-century German philosophy, developing natural sciences, humanities as well as dialectical and historical materialism. Both sciences developed in many varieties: philosophical and speculative social pedagogy, sociological pedagogy (practiced by educators), pedagogical sociology (practiced by sociologists), sociol-

${ }^{3} \mathrm{~W}$. Theiss, Where do we come from, what do we come with? On the ways of social pedagogy development, [in:] Social pedagogy in the face of threats to the human and the idea of social justice, vol. 2, Eds. W. Danilewicz, W. Theiss, Warsaw 2014, p. 70.

4 More widely in: W. Theiss, Where do we come from, what do we come with?

5 See Educational work. Its tasks, methods, organization, Ed. T. Bobrowski et al., Kraków 1913, p. 3 and $n$.

${ }^{6} \mathrm{H}$. Radlińska, The educator's attitude towards the educational environment. Sketches from social pedagogy, Warszawa 1935, p. 240. This study contains an outline of social pedagogy. Its subject, separate from the sociology of education, is clearly approaching social policy and pedagogy of culture and sounds like "the interaction of environmental influences and the forces of individuals that transform the environment, and in the name of the cause the education transform this very day with human forces". 
ogy of upbringing (recognizing the problems of social functions or processes of education in the theoretical-sociological system as a field of sociology). ${ }^{7}$

Not without significance, according to M. Cichosz, was the impact of "(...) the idea of radical socialism (Ludwik Krzywicki, Edward Abramowski), with a clear reformist and even revolutionary attitude in relation to particular phenomena of social life; on the other hand - about the impact of such ideas adopted in the sociology of upbringing (Florian Znaniecki, Jan Stanisław Bystroń) as: assumptions about the crucial educational impact of environmental factors (it seems that social pedagogues have often recognized environmental determinism here), adopting the concept of personality as a mechanism of behavior shaped on the path of $>$ growing < of the individual into culture or treating the whole institution of "educational society" (F. Znaniecki) as a subject of education, and a person in all phases of their life as an object of influence. ${ }^{8}$ The mentioned author adds that the ideas of the new education movement were also of extreme importance for social pedagogy ${ }^{9}$

Thus, Polish social pedagogy vividly falls under the current trends of social sciences, drawing many important inspirations for them. This diversity and multi-threading at the level of concepts being accepted caused many scientific debates about its social scientific identity, understanding of the main concepts as well as relationships with other scientific disciplines, especially the sociology of education. ${ }^{10}$ They were conditioned by the current political and social situation which dominated in science and by the problems specific to that situation in Poland at that time. These debates concerned primarily the interpretation of the concept of educational environment and the importance of institutions in creating that environment. ${ }^{11}$ The sociology of education,

7 S. Kowalski, Social pedagogy of Helena Radlinska and sociology of education, Sociological Studies, 1980, 3, p. 7.

${ }^{8}$ M. Cichosz, Triptych about social pedagogy - reflections at the turn of the century, Social Pedagogy, 2003, 3, p. 13.

9 Ibidem, p. 148. See also J. Sobczak, "New education" in Polish pedagogy of the Second Polish Republic (1928 - 1939), Bydgoszcz 1998.

10 Zob. R. Wroczyński, Helena Radlińska - pedagogical activity and system, [in:] H. Radlińska, Social pedagogy, Warsaw 1961; A. Kamiński, The scope and basic concepts of Helena Radlińska's social pedagogy, [in:] there see J. Chałasiński, Thirty years of Polish sociology 1918-1947, Sociological Review, 1937, 5; W. Wincławski, Development of sociology of education in Poland, Cultur and Society, $1977,3$.

${ }^{11}$ In 1969, on the pages of Kwartalnik Pedagogiczny no. 3 an article by Aleksander Kaminski was published. Its title was Social pedagogy - an attempt to characterize it. In this article, Aleksander Kamiński presents his doubts which he responds to, referring, among others to the thought of Stanisław Kowalski regarding the relationship between social pedagogy and the sociology of education. Whereas Wiesław Theiss in his article Where do we come from, what do we come with? On the ways of social pedagogy development presented in the book Social pedagogy in the face of threats to the human and the idea of social justice, edited by W. Danilewicz, W. Theiss, vol. 2, Warsaw 2014 on page 73 draws our attention to the interesting discussion that took place be- 
which has the character of an explanatory and empirical description, became particularly close to social pedagogy.12

Social pedagogy by H. Radlińska was and still is close to some concepts of sociology of education. The polemics about the covenant of social pedagogy of H. Radlińska with sociology of education are also of great importance nowadays due to the cooperation of social pedagogues and educational sociologists, especially in research on the educational process, where pedagogues, improving their research skills, often refer to the sociological knowledge system ${ }^{13}$

The purposefulness of underlining the relationship between social pedagogy and the sociology of education is confirmed by Stanisław Kowalski when he states that:

(...) Social pedagogy as a theory of practical action must refer to various other sciences (...), however, sociology, in particular sociology of upbringing, - as a discipline dealing primarily (...) with methods of "repairing" socio-educational environments (...) - is its basic reference discipline, as it mainly deals with the analysis of the structures and functioning of social environments. It was in this mutual relation that both disciplines developed and shaped their methodological separateness. ${ }^{14}$

\section{S. Kowalski further believes that:}

we can talk about two scientific subdisciplines: diagnostic and explanatory sociology of education as a field of sociology, and practical social pedagogy as a subdiscipline of pedagogy. ${ }^{15}$ According to him the common features of both disciplines include: „increasing desire to rely on empirical research; broad understanding of education, including both unplanned environmental impacts on the development and socialization of the individual. (More common features include) intentional management of these processes, overcoming biopsychological or nativist assumptions in the understanding of educational processes, and adopting assumptions about the decisive, educational impact of environmental factors, which some systems transform to extreme environmental determinism; replacement of the traditional understanding of personality as a set of mental features developed in specific environmental conditions, and the concept of personality as a mechanism of behavior shaped by the "ingrowing" of the individual into the culture and system of social roles; adopting as the subject of upbringig

tween Florian Znaniecki and Helena Radlińska in Kazimierz on the Vistula between 8 - 9th of May, 1929. It concerned the different approaches of both subdisciplines to upbringing and pedagogy. As a result of this discussion, more positions related to social pedagogy emerged, developed by, among others Stanisław Kowalski, Jan Konopnicki and Romana Miller. Additionally, scientific programs of Ryszard Wroczyński, Aleksander Kamiński and Irena Lepalczyk were established.

${ }_{12}$ B. Matyjas, Z. Ratajek, E. Trafiałek, Orientations and trends in contemporary pedagogy, Kielce 1997, p. 88-98.

${ }^{13}$ S. Kowalski, Social pedagogy of Helena Radlińska, p. 6.

${ }^{14}$ Ibidem.

${ }^{15}$ Ibidem, p. 9. 
not only the direct education institution, but the whole institution of the "educational society" and its various environments, and as an object of upbringing - people, of all ages - children, youth, adults and the elderly. ${ }^{16}$

Social pedagogy and sociology of upbringing are connected by a common subject of research, which is the educational process and its similar perception. It was described by the author mentioned above in the following words:

(...) a review of the work of continuators of the work of H. Radlinska suggests a hypothesis that, although this development has been particularly marked in recent years by an evident striving to improve the methodology on the premises of praxeology and social engineering - it dominated, often by creative adoption of the achievements of sociology (in studies of educational environments) or psychology (in diagnosing individual cases).${ }^{17}(\ldots)$ On the other hand, both the disciplines are divided by the approach to this common subject of diagnostic and exploratory research on the side of sociology of education, analyzing the course, functions and conditioning of educational processes using sociological methods and systems of knowledge - on the side of social pedagogy seeking ways of effective educational action for actual practice ${ }^{18}$ recognizing and activating "human / social forces" in the environment. In this sense, social pedagogy represents a line in thinking about man and upbringing with a concept focused around issues of supporting the development of "human / social forces". ${ }^{19}$

Social pedagogy and sociology of upbringing, therefore, examining the educational process and its conditions, put research problems for the use of their own discipline and solve them in a different way. Both of these disciplines move towards researching all aspects of the space in which educational processes are updated. „Sociology of education, using research methods and sociological knowledge systems, analyzes the correctness of upbringing processes. On the other hand, social pedagogy, guided primarily by methodological premises and the pedagogy's knowledge system, poses and solves praxeological problems".${ }^{20}$ Sociology of education is an explanatory and descriptive science, while pedagogy is focused on practical and rational activities aimed at improving the structures of social levels of education (that, its research nature is praxeological). H. Radlińska also pointed out that social pedagogy is an interdisciplinary science. For its own purposes, it uses basic research in the fields of biology, psychology and sociology ${ }^{21}$

Recently, we have noticed intense changes taking place in the area of social, cultural, economic and political life, which cause a rapid acceleration of

\footnotetext{
${ }^{16}$ Ibidem, p. 10.

17 Ibidem, p. 17.

${ }^{18}$ Ibidem.

19 A. Kamiński, Social pedagogy - an attempt at characteristics, Pedagogical Quarterly, 1969, 3.

${ }^{20}$ S. Kowalski, Social pedagogy of Helena Radlińska, p. 50.

${ }^{21}$ W. Theiss, Radlińska, Warsaw 1984, p. 69-70.
} 
civilization changes on a global and local scale. This way the interest of many humanities specialists in the problems of upbringing and socialization has increased significantly. This has created the need for integrative and interdisciplinary pedagogical research, as well as for developing specific educational directives. Finally, it should be emphasized that modern social pedagogy and sociology of education face the necessity of being in mutual relationship in order to use multiple concepts and theories to create pedagogical and sociological diagnoses, adopting various models of solutions undertaken as part of activities related to upbringing and education. In addition, social pedagogy as a practical discipline deals with prevention, compensation and therapy by linking its narrative to human needs in the name of the idea of social justice ${ }^{22}$

\section{Social pedagogy and sociology of upbringing in the face of new phenomena of social civilization}

The dynamic changes of the modern world, undoubtedly associated with the globalization process and the accompanying consumption, constitute a complex interdisciplinary topic that has settled for good in numerous scholarly narratives and discourses. It is also a kind of imperative prompting new thinking about various aspects of reality, i.e. economic, technical, social, cultural, educational, political and ecological as well as engaging in other empirical research and practical activities. It is also important to emphasize the important role of experts in this topic, i.e. people directly involved in solving problems related to various spheres of life and people designing changes that promise to improve the fate of human beings.

The development of civilization and rapid changes in the lives of societies make individuals exist among objects and not among other people. Modern forms of communication loosen interpersonal relationships. The multitude of possibilities of the modern world in making choices forms the basis for building your own identity. The pursuit for "more" is now deciding about the purpose of most people's aspirations. The development of the consumption ethos, where ubiquitous consumption and pleasure have become a measure of quality of life is a disturbing phenomenon. The concepts of globalization, mass culture and consumption are the basic ideas of modern societies. This intensifies the diversity of living conditions. Some feel the pleasure of having consumer goods while others struggle with poverty and hunger. The list of social and pathological problems is growing. So questions about the shape of future generations and the future of the world are beginning to appear.

${ }^{22}$ A. Kamiński, Functions of social pedagogy, Warsaw 1980, p. 15. 
The era of "Temples of Consumption" has come, and the world is constantly getting lost in them, while losing "moments" in the lives of individuals, and sometimes the most important moments. The only way to be happy is to "stop" and reflect on the value of human life.23 Not only the huge scale of consumption phenomenon is worrying, but also the fear for the future of young generations, because, according to Antoni Kępiński:

In addition to biological inheritance, human is also a subject to social inheritance, thanks to which they can possess certain material and spiritual values. The effort of thousands of generations associated with the creation of speech, writing, the news about the world and morals as well as art and technical devices, etc. has been passed on to them since birth.. If people were deprived of this legacy, they would have to start over again. The development of culture would be impossible. ${ }^{24}$

The challenges of globalization, regarding the indicated dimensions of reflection, refer in particular to pedagogy and sociology, including social educators and educational sociologists. It is worth considering the new challenges faced by both sub-disciplines at this point. An important role can be played by sciences that oscillate around problems related to the functioning of the human life environment and education related to that environment with a special prominence of upbringing.

And so, the sociology of education, which is the subject of our interest here, develops in many areas concerning: components of the educational environment (family, school, peer group, local environment), of the process of socialization of children and youth and the disorders of that process, improvement of the education system and finally education and upbringing in various environments. ${ }^{25}$ To this day, the representatives of sociologism share a belief in the leading role of the environment in shaping personality of an individual. The claim about becoming a "social being" as a result of participation in social life obliged pedagogues to pay attention to the social and cultural determinants of human development. This gave rise to concepts that emphasized factors working from the environment, which gave the upbringing process a new sense and scope and expanded it to include the broadly understood socialization of the individual. ${ }^{26}$

${ }^{23}$ More widely in: inter alia.: Z. Melosik, Popular culture as a factor of socialization, [in:] Z. Kwieciński, B. Śliwerski, Pedagogy 2, Warsaw 2003; A. Aldridge, Consumption, Warsaw 2006; G. Ritzer, The magical world of consumption, Warsaw 2012.

${ }^{24}$ A. Kępiński, The rhythm of life, Cracow 1992, p. 33.

25 S. Kowalski: An outline of sociology of education, Warsaw 1974, p. 60. More widely in: J. Modrzewski, Socio-pedagogy. Studies - sketches - reflections - memories, Poznań 2016; W. Ambrozik, J. Modrzewski (Eds.), The issue of education in the work of Polish sociologists (source materials for teaching sociology of education), vol. 1 Selection of texts, Koszalin 1998.

${ }^{26}$ B. Matyjas, Z. Ratajek, E. Trafiałek, Orientations and trends, p. 88. 
The upbringing process as the subject of research of sociology of education is treated as a component of general social development, whose main function is to pass culture to growing generations and to prepare for active participation in socio-cultural progress. In the process of civilization development, upbringing differs in different types of societies. It proceeds differently within a particular socio-political system, in different layers and social classes, various local communities, etc. It also differs in individual educational institutions. ${ }^{27}$ Therefore, the most important research problems of sociology of education concentrate on the following issues:

- education system facing the socio-economic and cultural changes,

- school selection mechanism,

- functioning of educational institutions in a local environment,

- structure and functioning of various environments,

- family upbringing functions,

- issues related to the functioning of universities - problems of the teaching profession,

- socialization and resocialization processes,

- youth issues ${ }^{28}$

On the other hand, social pedagogy has been always dealing with the theory of environmental conditioning of human education and development, as well as the theory and practice of shaping the environment (H. Radlinska 1935, 1961, R. Wroczyński 1985, A. Kamiński 1980). Therefore, creating the conditions for creative human development has always been its main goals. This activity covers social conditions, the sphere of moral values and principles, culture and tradition. It applies to individuals as well as groups or entire social environment. ${ }^{29}$ According to the above-mentioned authors - Helena Radlińska had always wanted to build a "better future" through education, highlighting the importance of education. In solving complicated problems of shaping human forces, there is a need for education perceived as meeting other people, specific individuals, a need to meet oneself as well as traditions, a world of values that the traditions embraces, it is also a meeting with dreams of a better future. It is noticed how close the relationship between thinking about a human and upbringing and contemporary concepts focused around the issues of supporting the development of "human forces"

${ }^{27}$ Ibidem, p.16.

${ }^{28}$ See. J. Jędrzejewski, Selection of texts from the sociology of education, Warsaw 1981, p. 6. You may also find it in: F. Znaniecki, Sociology of education, vol. 2; W. Wincławski, The development of Polish sociology of education in the light of the reception of F. Znaniecki during the Second Polish Republic, Culture and Society, 1977, 3; J. Włodarek, Sociology of education in the People's Republic of Poland, Sociological Studies, 1965, 3-4, p. 154; J. Modrzewski, Socio-pedagogy. Studies - sketches - reflections - memories.

${ }^{29}$ A. Przecławska, W. Theiss, Social pedagogy. Circles of search, Warsaw 1996, p. 9-29. 
is. ${ }^{30}$ The driving forces in changing and building reality are the possibilities of the environment - social (human) forces, understood as dynamics directed at making it "better". ${ }^{31}$

Social pedagogy in its theoretical theses and postulates for empiricism clearly prefers environmental education (over individual and group education) consisting of planned educational activity in environments that should aim at transforming the life environment of people by means of the forces of the people themselves. ${ }^{32}$ For human forces are the result of active attitudes in which we hope for a better tomorrow, for change and democracy. Therefore, the issue of the postulate of awakening social forces inherent in a given environment and thus promoting human subjectivity is still valid. ${ }^{33} \mathrm{~T}$. Lewowicki notes that pedagogy: „has been undertaking numerous tasks resulting from individual and group needs, appearing at a specific time and in a specific place, under certain circumstances". ${ }^{34}$ Therefore, the necessary part of the analysis of socialization and educational processes in the environment is knowledge of the social context and the conditions of their course. E. Marynowicz-Hetka states that:

This requirement is necessary, especially when we ask questions about the future, about the reality that is being created. This issue is particularly important when reflection on education in Poland, its dimension and its local threats is related to the European context of this issue. ${ }^{35}$

Shaping, creating or improving the socio-cultural environment with its own forces in the name of the idea is, according to the creators of social pedagogy: H. Radlińska, R. Wroczyński and A. Kamiński - environmental education. ${ }^{36}$

${ }^{30}$ A. Giddens, Modernity and identity. "I" and society in the age of late modernity, Warszawa 2001.

31 A. Przecławska, W. Theiss, Social pedagogy: new tasks and opportunities, Educational Forum, 1995, 1-2.

32 S. Kawula, Social support - a key dimension of social pedagogy, Care and Education Problems, 1996, 1, p. 6-7.

${ }^{33}$ W. Ciczkowski, Aleksander Kamiński's path to becoming an educator and scholar, [in:] The wealth of life and creativity, Eds. I. Lepalczyk, W. Ciczkowski, Torun 1999, p. 11-31.

${ }_{34}$ T. Lewowicki, Humanities and pedagogy (introductory remarks), [in:] Pedagogy in contemporary humanistic discourse, Ed. T Lewowicki, Warszawa - Kraków1999, p. 19 and n.

${ }^{35}$ E. Marynowicz-Hetka, Education in the environment and its threats, [in:] Social pedagogy. Questions about the 21st century, Eds. A. Przecławska, W. Theiss, Warsaw 1999, p. 123.

${ }^{36} \mathrm{M}$. Winiarski in his book Family - school - local environment. Problems of environmental education, Warsaw 2000 writes that environmental education as a social phenomenon is "a sequence of changes taking place in the local environment regarding education, upbringing, care, social assistance, cultural education and that is taking place through the social forces of this environment" see p. 13. When addressing the issue of education in the environment, it is worth mentioning the concept of H. Radlińska's social work, showing the essence of social activities in the environment and aimed at creating a community. 
It is worth recalling that in contemporary environmental pedagogy, the ideas still valid to this day had been mentioned for a long time by the classics: H. Radlińska, R. Wroczyński and A. Kamiński. These include: - the idea of social education (upbringing is an autonomous field of creativity, and at the same time one of the elements of social and cultural life); - the idea of subjectivity ("human forces" are the creators of the social world as well as dynamic and variable structure); - the idea of social justice (all people should have equal access to development conditions; this opportunity is guaranteed by a social order based on democracy) and the idea of subsidiarity (society has a duty to help all groups and social environments who are in need of development). ${ }^{37}$ A. Przecławska and $\mathrm{W}$. Theiss believe that these ideas:

based on universal values have withstood the test of time and are still helpful in building a better world. The world, by overcoming various meanders of its development, is on occasion approaching these values or is moving away from them. ${ }^{38}$

It should also be emphasized that social pedagogy as a humanistic science faithfully defends man against the threats posed by the development of civilization. Ultimately understood as both pedagogical theory and environmental practice, it plays a service role in social service, taking into account the specificity of human needs ${ }^{39}$

Today's world, being so dynamic and diverse and at the same time global, creates new characters by means of the processes of upbringing and socialization. The scope of interests of social pedagogy and sociology of education is intensively expanding to include all institutions and spaces of social life. This presents new challenges for social pedagogy and sociology of education. Recalling the above mentioned, synthetically selected areas of interest of both disciplines induces us to final reflection, in which the importance and servitude of both disciplines towards man and society should be emphasized. Research results and subsequent sociological and pedagogical diagnoses to a certain extent give a new and current perspective to both subdisciplines, enriching the environmental point of view with new concepts and theories regarding education and socialization. On the other hand, the fruit of mutual cooperation between social pedagogy and the sociology of upbringing is, according to Stanisław Kowalski ${ }^{40}$ the improvement of methods of effective pedagogical

\footnotetext{
37 S. Kawula, Social support - a key.

38 A. Przecławska, W. Theiss, Social pedagogy, p. 9-28.

39 B. Matyjas, Z. Ratajek, E. Trafiałek, Orientations and trends, p. 98.

40 S. Kowalski, Social pedagogy of Helena Radlińska, p. 23.
} 
action in the environment, which in turn can give hope to many people and groups in overcoming difficult existential problems of man to create a better tomorrow.

\section{BIBLIOGRAPHY}

Aldridge A., Consumption, Warsaw 2006.

Ambrozik W., Modrzewski J. (Eds.), The issue of education in the work of Polish sociologists. (source materials for teaching sociology of education), vol. 1 Selection of texts, Koszalin 1998.

Bobrowski T. et al., Educational work. Its tasks, methods, organization (editor), Cracow 1913.

Cichosz M., Triptych about social pedagogy - reflections at the turn of the century, Social Pedagogy, 2003, 3 .

Ciczkowski W., Aleksander Kaminiski's path to becoming an educator and scholar, [in:] The wealth of life and creativity, Eds. I. Lepalczyk, W. Ciczkowski, Torun 1999.

Giddens A., Modernity and identity. "I" and society in the age of late modernity, Warsaw 2001. Jędrzejewski J., Selection of texts from the sociology of education, Warsaw 1981.

Kamiński A., Social pedagogy - an attempt at characteristics, Pedagogical Quarterly, 1969, 3.

Kamiński A., Functions of social pedagogy, Warsaw 1980.

Kawula S., Social pedagogy, Eds. T. Pilch, I. Lepalczyk, Warsaw 1995.

Kawula S., Social support - a key dimension of social pedagogy, Care and Education Problems, 1996, 1.

Kawula S., Studies on social pedagogy, Olsztyn 1996.

Kawula S., Social Pedagogy. Achievements - activity - perspectives, Torun 2001.

Kępiński A., The rhythm of life, Cracow 1992.

Kowalski S., An outline of sociology of education, Warsaw 1974.

Kowalski S., Social pedagogy of Helena Radlinska and sociology of education, Sociological Studies, 1980, 3.

Lewowicki T., Humanities and pedagogy (introductory remarks), [in:] Pedagogy in contemporary humanistic discourse, Ed. T. Lewowicki, Warsaw - Cracov 1999.

Marynowicz-Hetka E., Education in the environment and its threats, [in:] Social pedagogy. Questions about the 21st century, Eds. A. Przecławska, W. Theiss, Warsaw 1999.

Matyjas B., Ratajek Z., Trafiałek E., Orientations and trends in contemporary pedagogy, Kielce 1997.

Melosik Z., Popular culture as a factor of socialization, [in:] Z. Kwieciński, B. Śliwerski, Pedagogy 2, Warsaw 2003.

Modrzewski J., Socio-pedagogy. Studies - sketches - reflections - memories, Poznań 2016.

Przecławska A., Theiss W., Social pedagogy: new tasks and opportunities, Educational Forum, 1995, 1-2.

Przecławska A., Theiss W., Social pedagogy. Circles of search, Warsaw 1996.

Radlińska H., The educator's attitude towards the educational environment. Sketches from social pedagogy, Warsaw 1935.

Radlińska H., Social causes of school successes and failures, Warsaw 1937.

Ritzer G., The magical world of consumption, Warsaw 2012.

Sobczak J., "New Education" in Polish pedagogy of the Second Polish Republic (1928-1939), Bydgoszcz 1998.

Theiss W., Radlińska, Warszawa 1984. 
Theiss W., Social pedagogy of the Second Polish Republic (questions about scientific discourse), [in:] Social pedagogy. Tradition - The Present - New challenges, Ed. E. Trempała, M. Cichosz, Olecko 2001.

Theiss W., Where do we come from, what do we come with? On the ways of social pedagogy development, [in:] Social pedagogy in the face of threats to the human and the idea of social justice, vol. 2, Ed. W. Danilewicz, W. Theiss, Warszawa 2014.

Wincławski W., The development of Polish sociology of education in the light of the reception of F. Znaniecki during the Second Polish Republic, Culture and Society, 1977, 3.

Winiarski M., Foreword. Living and education environment in the perspective of globalization, [in:] Animation of the environment versus education and upbringing for the needs of tomorrow, Eds. K. Segiet, K. Słupska-Kwiatkowska, Gniezno 2010.

Włodarek J., Sociology of education in the People's Republic of Poland, Sociological Studies, 1965, 3-4.

Znaniecki F., Sociology of education, Educational Theory 1951, 2. 